\title{
Exploring the Main Barriers of Technology Integration in the English Language Teaching Classroom: A Qualitative Study
}

\author{
Rouholllah Khodabandelou (Corresponding author) \\ Faculty of Education and Languages, HELP University, Wisma HELP, Jalan Dungun, Kuala Lumpur, 50490, Malaysia \\ E-mail: r.khodabandeh@help.edu.my \\ Junny Ei Mon That \\ Faculty of Education and Languages, HELP University, Wisma HELP, Jalan Dungun, Kuala Lumpur, 50490, Malaysia \\ E-mail: un8mt@googlemail.com \\ Melinda Anne A/P S.Selvaraju \\ Faculty of Education and Languages, HELP University, Wisma HELP, Jalan Dungun, Kuala Lumpur, 50490, Malaysia \\ E-mail: melindaanne@ymail.com \\ Tan Yan Ken \\ Faculty of Education and Languages, HELP University, Wisma HELP, Jalan Dungun, Kuala Lumpur, 50490, Malaysia \\ E-mail: darken_king@yahoo.com \\ Zhu Kewen \\ Faculty of Education and Languages, HELP University, Wisma HELP, Jalan Dungun, Kuala Lumpur, 50490, Malaysia \\ E-mail: rosella.zk@gmail.com \\ Zhang Yan \\ Faculty of Education and Languages, HELP University, Wisma HELP, Jalan Dungun, Kuala Lumpur, 50490, Malaysia \\ E-mail: oligo0401@gmail.com \\ Tan Yan Ning \\ Faculty of Education and Languages, HELP University, Wisma HELP, Jalan Dungun, Kuala Lumpur, 50490, Malaysia \\ E-mail: yanning@live.com
}

Received: 02-11-2015

Accepted: 28-01-2016

Published: 31-01-2016

doi:10.7575/aiac.ijels.v.4n.1p.53

URL: http://dx.doi.org/10.7575/aiac.ijels.v.4n.1p.53

\begin{abstract}
The abundance of technology in recent years has contributed to development in the societies, industries, and education. It is proven from the current trend of technology such as the emergence and rise of smart phones, tablets, laptops and wireless internet connection that the present and future world will be heralded by technology. The integration of technology into the teaching and learning process is idealistic with the existence of vast information and multimedia on the internet and innovative inventions of devices that serve as great assistance. However, the available technology has not been put to good use in the English language teaching and learning classroom for some reasons, especially in developing countries like Malaysia. Thus, this research is conducted to determine the hindrances faced by the education community in Malaysia. The current qualitative research involved seven individuals who discussed issues relating to the hindrances of technology integration in English language teaching and learning. This paper presents the results of the discussion and provides suggestions on some possible solutions to the identified obstacles faced by the education community in using technology in a more efficient and resourceful manner for the teaching and learning development.
\end{abstract}

Keywords: TESL, barriers, technology, integration, higher education

\section{Introduction}

In today's world, people are more and more extensively connecting with technology due to its accessibility and availability via electronic gadgets. Modern technology benefits people in many different aspects such as in communication, transportation, medical and health care. Most business and organizations are using technology as 
essential tools to promote and market their products and services. Information Technology is also changing the behavior and nature of education in developed and developing countries. Computer, Internet, Mobile dictionaries, LCD Projectors, DVD players, e-books and e-learning systems have been introduced and used in many universities and schools (Mahmood, 2015). People believe that new technologies will support education system in the future because they provide more effective communication and better understanding to users (Dawes, 2001). The Malaysian government is encouraging schools and universities to engage with new information technologies in both urban and rural areas (Kumutha \& Hamidah, 2014). Most Malaysian private universities are equipped with advanced technology teaching material and e-learning systems. But, not all the teaching classes' especially English Language Teaching classes are practically using those materials yet.

Computer and network technology are widely used in teaching; they are undoubtedly beneficial in the educational sector. Information Technology can produce richer curricula, enhanced pedagogies, teachers' higher work efficiency in schools. Technology integration has indeed become an important means for teachers in their daily teaching. Previously Kent and Facer (2004) indicated that school is an important environment in which students participate in a wide range of computer activities. Increasingly, Information Technology is being applied successfully in instruction, learning and assessment. Nevertheless, there are still factors that hinder the integration of technology in the English classroom. The current study investigated the main barriers in the way of technology integration from the perspectives of students and teachers. In other words, it aimed to identify the major hindrances of integrating technology in English language teaching classes.

\section{Literature Review}

Meany researches have shown the challenges of technology integration in teaching and learning. However, previous research focused on the area from a different and limited point of view. For instance, Frederick, Schweizer and Lowe (2006) investigated technology integration from students' point of view. They showed that "student mobility, special needs, and anxiety over standardized test results are the main challenges associated with ICT use" (p73). The biggest problem that students face in their reaction to technology is students may use technology to over-connect with the outside world. According to research, more and more students are addicted to the internet; some of them even quit school. Valentine (2002) argued that the problem in part originates from promoting autonomous learning in little supervised and observed conditions. Learning through computers and the internet, students cannot be well-organized and focused. Students' work cannot be acknowledged due to the lack of body language, eye contact and physical communication of the teacher when the learning from a distance; hence, responding to the work is often associated with laziness and lack of presence.

Several recent studies investigated the challenges of integrating technology in the teaching and learning process. For example, Xu (2010) stated that teachers are usually good and effective in conveying their message through all kinds of classroom communication, including body movements that give more visual guidance to students in addition to the audio input. However, the introduction of multimedia technology dampens the communication between the teacher and the students where students listen to sounds and images from the computer and they have lesser face-to-face speaking opportunity though it is said that technology can emulate what the teacher has said through the screen and speakers. The result of it is English language learning transforms into a courseware show with students viewed as the audience rather than the participants of classroom activities.

In another study, Whelan (2008) indicated that students' over-reliance on the internet will reduce their interaction with peers and instructors. It may cause students to be excluded from the group and even isolated from the world. Being involved in a cooperative learning method is an essential part of forming the online learning community. Students in these communities often feel more pressured to work together as a part of the group when participation is not seriously stimulated; hence, involvement is usually low when conversation is lacking (Valentine, 2002). Misunderstanding is not unusual in online conversation as the received messages are usually perceived differently. One may have difficulty understanding the responses of other people which can cause problems in the case of contrary opinions or miscommunication that can cause problems as the class progresses (Valentine, 2002).

$\mathrm{Xu}$ (2010) also added that English language learning requires students' thinking skills where questions posed to students are generally considered beneficial to their critical thinking and problem solving skills. However, courseware may not serve the purpose of triggering students' feedback in real-time and the less emphasis in teaching and appreciating English language when it only requires students to perform free learning or independent learning. Although to some extent multimedia helps in promoting students' thinking capacity, it should be distinguished that the cultivation of students' thinking should be the priority; any opportunity to prompt students to analyze, discover and explore questions should be embraced.

Numerous empirical studies show that both internal and external factors in the part of the teacher can hinder integrating technology in teaching and learning. The internal factors include teachers' attitude, which means teachers themselves may refrain from using technology in the classroom. Recent evidence suggests most teachers do not like to use computers because of their old ages; they expect younger people to learn and use it, while they believe that older practitioners do not have to use it anymore. Additionally they believe that they can use traditional methods to teach interactive lesson without using technology. Moreover, for those teachers who have years of working experience, they prefer using manual ways instead of use projectors (Kumutha \& Hamidah, 2014). 
The external factors are due to the teacher's lack of time to prepare the power point or similar materials for students. Surveys such as the one conducted by Kumutha and Hamidah (2014) have shown that the majority of respondents complained that they were too busy to mark students' homework and examination papers, in addition, they were forced to finish the syllabus assigned by school. Using technology in the classroom is really time consuming and they could not complete the school syllabus. Indeed, technology integration in classroom is a burden for them. At times, teachers are not committed to this kind of learning-teaching method, which is not in the classroom but in distant places. The concerns include the support and recognition by the administration while the time used for preparing the lessons lengthens the teaching and learning process (Valentine, 2002).

One more important external factor is teachers' lack of training to use technology. Some teachers may not have enough skill to incorporate technology tools because they did not attend any Information Technology training (Kumutha \& Hamidah, 2014). According to Han (2010), training and support improve gradually and they contribute to the integration of technology and efficiency of the teachers' teaching methods. It is unfortunate that some teachers do not put their expertise to good use when they teach large classes where it is quite impossible for the teacher to use the improvised ways of teaching in a lesson due to the size constraint. Without doubt that the information age promotes new teaching ways, imposing new requirements on the teacher. Han (2010) added that teachers are expected to be wellversed in technology in order to achieve the expected outcome, which often proves as a great challenge for the teachers. In spite of the ideal learning method that proudly encourages students to take advantage of the existing multimedia learning tools, teachers are mostly not well-trained in mastering the computer technology.

According to $\mathrm{Xu}$ (2010), multimedia technology's role in teaching and learning is only to assist, rather than entirely taking over the teaching process that can be seen in many situations where teachers put too much emphasis on the virtual courseware rather than the actual real-life teaching. Students would most certainly not communicate with their teachers when their job is only to look at the screen, rather than being engaged in the teacher's lesson, hence restricted the overall authentic teaching and learning environment. Xu (2010) added that the domination of technology in the classroom should be identified and restricted as the modern technology serves only as an assisting tool adopted to help teachers carry out an English language lesson, then it serves its purpose as brilliant teaching equipment that can really deliver its value.

The education system and education policy play a role in determining the way and the materials the schools should conduct the teaching. It is a positive sign when the government decides to improve the ICT facilities and environment of schools. However, it might prove insufficient when the implementation does not apply to the curriculum, at least not clearly stated or not at par to the objective of the technology development.

According to Williams (2000), many schools in the developed countries are teacher-based in the classroom even though the government has provided the entire infrastructure in the school. Therefore, appropriate administrative action should be conducted. Yildirim (2007) also indicated that school inspectors focus more on the quality of the course content and students' test paper more than on the Information Technology use, hence, the education system and content need to improve.

Another problem is the school may lack funding to buy basic infrastructure, appropriate hardware, software and materials; therefore, students cannot familiarize with the technology. According to Han (2010), the multimedia technology makes the content easier to deliver and comprehend, improving the course outcome. Some schools have insufficient multimedia classrooms or have equipment with low quality that does not serve its best potential to teaching process, thus maintenance is a constant nuisance as the cost, functionality and manageability add up to the teacher's workload.

Han (2010) maintained that most schools choose a large classroom as a high competence multimedia room which can cater to more students conveniently at a time; however, it may not be helpful in English language teaching and learning as it may not create an encouraging environment for active and effective student participation that would be more common in smaller classes. Somehow, the multimedia-supported teaching frequently lacks adequate facilities.

In summary, review of literature showed that there are some barriers to technology integration which have been highlighted in previous research such as reduced interaction $(\mathrm{Xu}, 2010)$, lack of effective communication (Whelan, 2008), low involvement (Valentine, 2002), less promotion of students' higher order thinking (Xu, 2010), teacher attitude, and educational system policies (Yildirim, 2007). However, all the previously mentioned methods suffer from some serious limitations. For example, few of them investigated from limit point of view. The current study comes to fill in this gap by investigating technology integration barriers in the English Language Teaching Classroom.

\section{Method}

This qualitative research used a focus group approach to gather the data. Tong, Sainsbury and Craig (2007) indicated that qualitative methods have an explorative nature and enable scholars to explore and investigate the intricacy of phenomena happened in the research area. Data collection method in qualitative research design in contrast with quantitative research design leads to a more in-depth understanding of the intended phenomenon (Khodabandelou, Karimi, \& Ehsani, 2015). Focus groups have been identified as a special type of group interview that is structured to gather detailed opinions and knowledge about a particular topic from selected participants (Bader \& Rossi, 2002, p 6).

A group of 7 postgraduate students in the field of Teaching English as Second language (TESL) studying in a Malaysian 
private university were purposively selected in order to participate in the study. Having at least a two-semester experience at the postgraduate level and willingness to participate in the study were the inclusion criteria to choose the respondents. Out of these 7 student-teachers, 5 were male and 2 were female. The participants were from different countries including Malaysia, India, China and Ghana. All participants had TESL background.

The focus group interview was carried out at a time and place convenient for the students on the university campus. At the end of the session, the participants were asked to add any supplementary information not addressed by the interviewer. So, data collection process was continued until reaching the saturation point. The whole focus group session lasted 100 minutes. It was recorded using a digital sound recorder. Immediately after the session, the content was transcribed verbatim.

\section{Findings}

Based on the data gathered from the focus group, four main hindrances to technology integration in the English classroom are identified. They are classified from four main factors including the teachers, students, education policy, and the environment issues. These factors are discussed in this section.

\subsection{Students}

The results of the focus group study showed that sometimes students are overloaded by all kinds of information. However, they have no idea which way is reasonable to choose relevant technology. Even teachers have no idea which way should be chosen to teach and which way is more beneficial for students. As one of the participants mentioned:

The younger the students are, the more easily they will lose focus in information explosion era. Besides, as online chatting is developing, students could have spelling problems. Sometimes, things can be totally opposite because since some teachers put teaching materials too complicated and too dazzled, students may don't have enough time to catch the points.

Sometimes online teaching can be tricky to some students because different students have different learning styles. Highly technological ways may be beneficial for some students, but not for others. In general, syllabus based on technological teaching methods may not be optimum for students because of its differences they differ from traditional teaching; technological method offers a unified standard. Sometimes for some students, they cannot adjust to this new evaluation system very well.

\subsection{Teachers}

Teachers can also be considered as one of the main barriers for technology integration. As some of the group members stated,

The teachers are not exposed to the technology. The teachers do not know how to use the technology to teach English.

This is because they were not trained how to use the technology or the software to teach the students. Building the authentic global online teaching and learning communities requires careful and thoughtful curriculum development as well as continuous technical and material support from the organization as well as the Education Ministry (Klein, 2010). So, it cannot be done through the individual contribution of teachers. It is also time-consuming for the teachers to choose the reliable media to teach the students. As noted by the focus group members:

For example, to check the validity of the article on the internet, the teachers, especially the teachers aged 50 and above, are not willing to involve themselves in using the technology.

Another issue raised by the teachers in regards to difficulties of using new technology is:

Teachers face some difficulties uploading their teaching materials onto the intranet. They are reluctant to use the technology by giving the excuse that they are too old to learn the technology.

Teachers may often feel bewildered when they see the numerous menus and options on the screen which they have never used before. They found it difficult to remember which buttons to click since they did had not received any training in advance. Therefore, training should be provided for the teachers to widen their knowledge on how the technology can ease their teaching processes. Teachers should learn how to use the software and use it in the English classroom.

\subsection{Educational system and policy makers}

Besides the drawbacks from teachers and student's points of view, Malaysia's educational system also hinders technology integration in the English language learning process. As one of the respondents pointed out:

The government has provided most of the schools with many ICT facilities such as computers, laptops, LCD projectors, etc. to ease students' learning process. However, teachers are not fully utilizing these facilities due to their unwillingness to adopt and practice modern and contemporary ways of teaching. Moreover, most of the teachers are computer illiterate. 
One of the participants addressed the barriers of technology integration in learning from educational system by recommending:

The government should create a policy to monitor teachers' learning styles. To be more specific, the government should appoint an educational officer particularly to train and monitor teachers' techniques and methods once a month or twice.

This is a vital effort as most of the teachers do not use the technology in schools since they have not been trained. As a result, teachers stay in their comfort zone by educating students in conventional ways such as teaching in classrooms with textbooks and whiteboards alone. Therefore, monitoring teachers monthly will consequently mold them to utilize and exploit technologies in daily teaching.

Teaching is enhancing critical thinking skills as students are constantly bombarded with information. Therefore it is necessary for teachers to integrate technologies in teaching.

Respondents indicate that sometimes technology itself has been provided for them but the policy makers fail to get the consideration from teachers.

Thus, it is important that the government or policy makers should train or educate teachers prior to integrating the technology in teaching process. Subsequently, governments should monitor and supervise teachers' teaching styles monthly. This is to ensure teachers are able to create innovative, constructive and fun learning environments for students.

\subsection{Environment}

The environment of technology in English language classrooms is sometimes not lesson-friendly or user-friendly as there are some shortcomings in facilities and the setting. One of the shortcomings is the quality of the equipment, as it sometimes is disappointing when the equipment owned is not suitable or not good enough for use:

The maintenance of the equipment is another worry for the schools as it does not provide convenience, but more difficulties for the teachers or the schools.

The classroom environment is another factor that affects the usage of technology in English language teaching and learning process.

The classroom environment is sometimes not suitable for projector slides as glares may interfere with the visibility of the presentation of the teacher's lesson.

Not only that, the electricity, air-conditioned room, and internet connection are some other concerns that the teachers find disturbing and halt some technology usage in the teaching of English language.

\section{Discussion and Conclusion}

Technology can facilitate teaching in the classroom, thus the government needs to promote its use in the education system. Most importantly, the government should provide support and sustenance to the schools to ensure the optimal use of technology. It is also necessary for the government to provide convenient environment and beneficial as well as valuable tools in the whole Malaysian education system, in line with the Malaysian Vision 2020.

In the previous studies such as Satharasinghe (2006) it was found that both teachers and students play roles in the impact of these investments and thereby can help ensure that the intended results are achieved. Information and Communication Technology (ICT) literacy of students and teachers should be monitored periodically by the government.

Teachers should be capable of changing their mindset to adapt technology and attend necessary training on the use of technology to equip themselves better before teaching students. Teachers should continuously attend training to use the technology in the English language classroom. It is important to remember that technology does not improve teachers' teaching and students' learning effectively without proper implementation and guidance to the usage of the tools such as computers and the internet. Hence, teachers have to use technology to its best function that is to assist in the teaching and to enhance students' activity and participation. The resources can be presented in many ways that the students can optimize their acquisition of knowledge. Teachers will accept the use of the technology if it assists them in some ways in the teaching and if they start seeing it as an advantage rather than a disadvantage. Consequently, technology will improve students' motivation and willingness to learn in an interesting yet meaningful English language learning environment.

\section{References}

Bader, G., \& Rossi, C. (2002). Focus Groups: A Step-By-Step Guide (3 ${ }^{r d}$ Edition). The Bader Group, Canada.

Bude, S. (2009). Effective technology integration: Old topic, new thoughts, International Journal of Education and Development using Information and Communication Technology, 5(2), 161-171. 
Dawes, L. (2001). What stops teachers using new technology? In Leask(Ed), Issues in Teaching using ICT (pp. 61-79). London: Routledge.

Frederick, G. R., Schweizer, H. \& Lowe, R. (2006). After the in-service course: Challenges of technology integration, Computers in the Schools, 23(1), 73-84.

Han, L (2010). The Advantages and the Problems of Multimedia-aided English Reading Instruction. Journal of Language Teaching and Research, 1(3), 320-323.

Jo, S. F. (2013). ICT in Education: A Critical Literature Review and Its Implications. International Journal of Education and Development using Information and Communication Technology, 1(1), 112-125.

Kent, N. \& Facer, K. (2004). Different worlds? A comparison of young people's home and school ICT use. Journal of Computer Assisted Learning, 20(4), 440-455.

Khalid, B. (2009). Barriers to the Successful Integration of ICT in Teaching and Learning Environments: A Review in Literature. Eurasia Journal of Mathematics, Science \& Technology Education, 5(3), 235-245.

Khodabandelou, R., Karimi, L., \& Ehsani, M. (2015). Challenges of International Higher Education Students in a Foreign Country: A Qualitative Study. Higher Education for the Future, 2(2), 165-174.

Klien, A. (2010). Education budget plan wielded as policy lever. Education Week, 29. Retrieved October 19, 2015 from: http://www.edweek.org/ew/articles/2010/02/10/21budget_ep- 2.h29.html

Kumutha, R., \& Hamidah, Y. (2014). Barriers Teachers face in Integrating ICT During English Lessons: A Case Study. The Malaysian Online Journal of Educational Technology, 2(3), 1-5.

Mahmood, M. (2015). The Perception of Students and Teachers About the Benefits of and Barriers to Technology Aided EFL. An International Peer-reviewed Journal, 13(1), 1-5.

Satharasinghe, A. (2006). Computer Literacy of Teachers. Retrieved October 19, 2015 from: http://www.statistics.gov.lk/education/article1.pdf

Selehi, H., \& Selehi, Z. (2012). Integration of ICT in Language teaching: Challenges and Barriers. 2012 3rd International Conference on e-Education, e-Business, e-Management and e-Learning, IPEDR Vol. 27, IACSIT Press, Singapore

Tong, A., Sainsbury, P. \& Craig, J. (2007). Consolidated criteria for reporting qualitative research (COREQ): A 32-item checklist for interviews and focus groups. International Journal for Quality in Health Care, 19(3), 349-357.

Valentine, D. (2002). Distance Learning: Promises, Problems, and Possibilities. Online Journal of Distance Learning Administration, 5(3), 1-11.

Whelan, R. (2008). Use of ICT in education in the South Pacific: findings of the Pacific eLearning Observatory. Distance Education, 29(1), 53-70.

Williams, M. D. (2000). Introduction: What is technology integration? M D Williams (Ed.) Integrating Technology into Teaching and Learning: Concepts and Applications. Singapore: Prentice Hall.

Xu, J. (2010). On The Problems and Strategies of Multimedia Technology in English Teaching. Journal of Language Teaching and Research, 1(3), 215-218.

Yildirim, S. (2007). Current utilization of ICT in Turkish basic education schools: a review of teacher's ICT use and barriers to integration. International Journal of Instructional Media. 34(2), 171-186. 